\title{
A CONTRIBUTION TO HOLOCENE SHORE DISPLACEMENT AND ENVIRONMENTAL DEVELOPIMENT IN VANTAA, SOUTH FINLAND: THE STRATIGRAPHY OF LAKE LAMIMASLAMPI
}

\author{
PENTTI ALHONEN, MATTI ERONEN, MILTON NÚÑEZ, \\ RISTO SALOMAA and RAIMO UUSINOKA
}

\begin{abstract}
ALHONEN, PENTTI; ERONEN, MATTI; NÚÑEZ, MILTON; SALOMAA, RISTO and UUSINOKA, RAIMO 1978: A contribution to Holocene shore displacement and environmental development in Vantaa, South Finland: the stratigraphy of Lake Lammaslampi. Bull. Geol. Soc. Finland 50: 69-79.

The sediments of Lammaslampi, a small lake situated about $32 \mathrm{~m}$ a.s.l. in Vantaa, were studied by means of pollen and diatom analyses and loss-on-ignition measurements. In addition x-ray diffraction analysis was used to examine the mineral composition of the basal part of the profile, and five radiocarbon determinations to date the local shoreline displacement. The basin was continuously connected to the Baltic until it became isolated as the result of the isostatic uplift after the Litorina transgression $6550 \pm 170 \mathrm{C}^{14}$ years BP. The »early Mastogloia phase» in the region was dated to c. $7700 \mathrm{BP}$ and the beginning of the Litorina stage to c. $7300 \mathrm{BP}$.

P. Alhonen, M. Eronen, M. Núñez, R. Salomaa and R. Uusinoka. Department of Geology, University of Helsinki, Snellmaninkatu 5, SF-00170 Helsinki 17, Finland.
\end{abstract}

\section{Introduction}

Lammaslampi is a small lake situated in southwestern Vantaa, some $12 \mathrm{~km} \mathrm{NW}$ of Helsinki $\left(60^{\circ} 16^{\prime} \mathrm{N}\right.$ and $\left.24^{\circ} 48^{\prime} \mathrm{E}\right)$. It is approximately $300 \times 200 \mathrm{~m}$ with its threshold at $31.8 \mathrm{~m}$ above the present sea level.

The purpose of this work is to describe within a chronological framework the various stages of the Baltic as reflected by the investigated sediment profile, and to deal with the palaeoecological development of the area in connection with the history of the Baltic and the isolation of Lake Lammaslampi.
No detailed shoreline investigations using modern methods have been carried out in Vantaa and, in this respect, the present results substantially complement the previously existing ideas concerning the shoreline displacement in the Helsinki area (see e.g. Hyyppä 1937, 1950; also Sauramo 1958, pp. 132152).

\section{Holocene environmental development in Vantaa}

The melting of the Weichsel ice lead to the submersion of most of the ice-freed areas, 


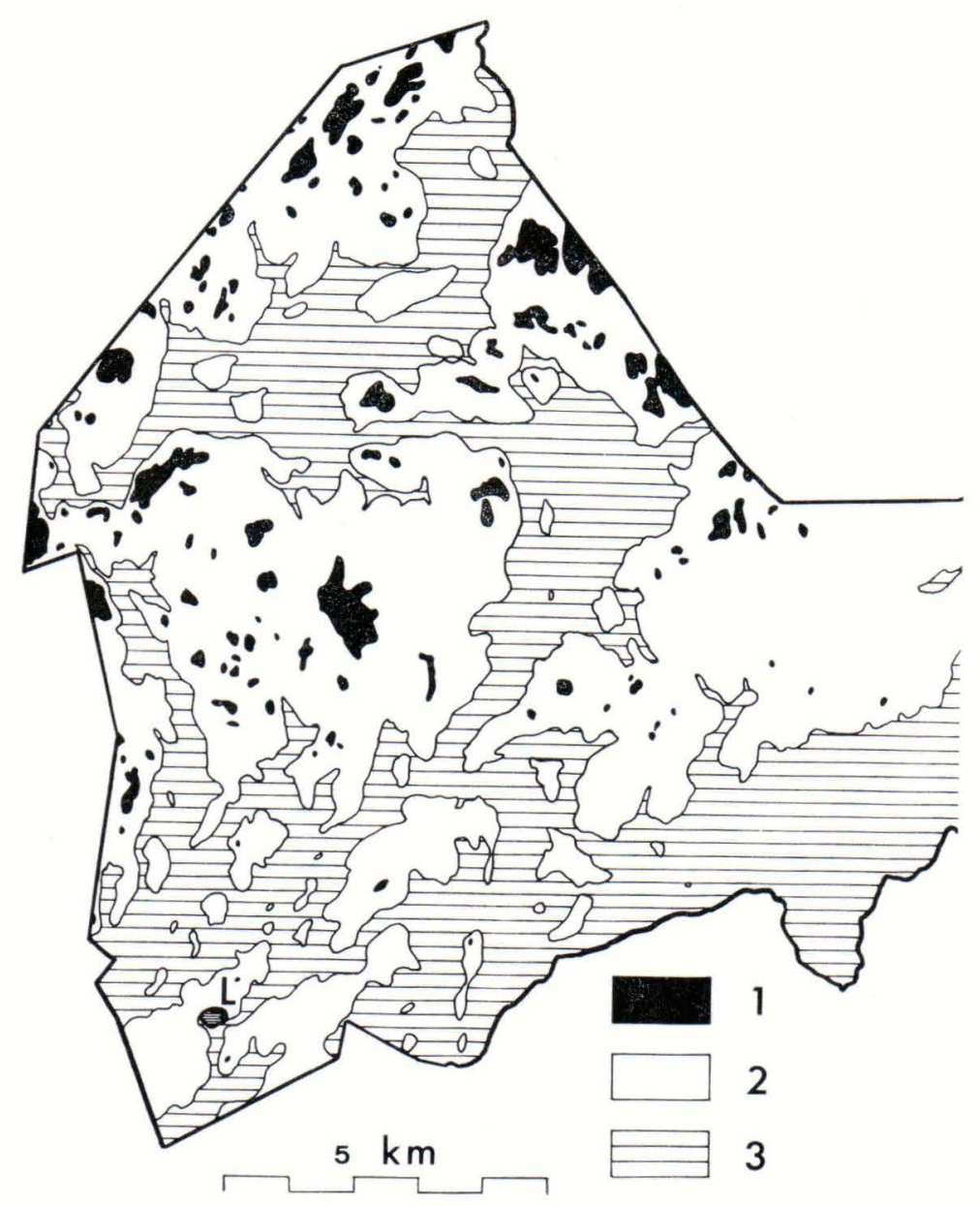

Fig. 1. Palaeogeography of western Vantaa during the Ancylus and Litorina transgressions and the location of the study site (M. Núñez): 1 = Dry land at the time of the Ancylus transgression maximum, $2=$ Dry land at the time of the Litorina transgression maximum, $3=$ Areas covered by the Litorina Sea at the transgression maximum. Lake Lammaslampi (L) can be seen at the lower left marked with close hatching. The map illustrates that the Lammaslampi basin formed at the beginning of the Litorina phase a shallow bay off a narrow sound within the existing Vantaa archipelago.

this also applying to the Helsinki district including Vantaa. Deglaciation was followed by land uplift which though slowed-down, still continues today. The isostatic uplift has therefore played a significant part in the development of the surficial deposits in the district, the wide valley-plain of the Vantaa river providing a characteristic local substratum for the sediments of the various Baltic stages.

As the icesheet retreated the Baltic basin became an ice-dammed lake: the Baltic Ice Lake which eventually receded to the ocean level about 10200 years ago. Although this event meant a $28-\mathrm{m}$ drop in the water level, Vantaa and the whole Helsinki district still remained under the waters of the subsequent Yoldia Sea. The water level at this stage was about $80 \mathrm{~m}$ higher than today (Hyyppä 1950) but by the end of the Yoldia period several skerries had already emerged in Vantaa. 
The highest Ancylus strand marks in Vantaa are found at altitudes of $50-60 \mathrm{~m}$. Dry land was still rare in the district: in the vicinity of Lammaslampi Ancylus strand marks occur on the slopes of Långbackaberget, Hämevaara, where the $62-\mathrm{m}$ summit stood only a couple of metres above the water. Hyyppä (1950, p. 44, Fig. 34) mentions the occurrence of Ancylus Lake raised beaches at $40-48 \mathrm{~m}$ a.s.l. in Östersundom, to the east of Helsinki. The Ancylus lake stage terminated with a rapid regression (Eronen 1976).

During the Litorina period the sea covered those areas in Vantaa situated up to $30-35$ $\mathrm{m}$ above the present sea level. Little is known about the changes in water level or the extent of the preceding influx of slightly saline water, which has been identified with the Mastogloia phase (cf. Eronen 1974). At Lammaslampi this phase is indicated by brackishwater diatoms within an otherwise fresh water flora.

The Litorina transgression was felt in the Helsinki district. Its peak took place around 7000 BP after which the shoreline displacement seems to have been a continuously regressive one, giving gradually shape to the present landscape.

Because of the relatively long period of submergence and the lack of major lake or peat deposits, the entire Holocene vegetation development in the area cannot be interpreted from organogenic sediments. The palaeogeographical map of western Vantaa as seen in Fig. 1 shows that by the beginning of the Litorina period there was enough dry land for the spread of vegetation into the area. In this respect the plant subfossils found in the Lammaslampi core are of particular interest (see p. 76).

The period of the Litorina Sea corresponds to the Holocene climatic optimum, when thermophilous trees (Corylus, Ulmus, Quercus, Tilia) were more common than today in the archipelago then formed by
Vantaa. The forests of this period were characterized by a dominance of deciduous trees.

With the climatic trend to colder and more humid conditions some 2500 years ago coniferous trees became dominant in the Vantaa forests. But due to the southern situation of the area the thermophilous species did not disappear and, for example, oak and hazel are still common around Lammaslampi, hazel even occurring as groves.

\section{Prehistoric man in Vantaa during the Ancylus and Litorina periods}

The arrival of Mesolithic man in southern Finland can be dated to around $9000 \mathrm{BP}$, or at least to the first half of the ninth millennium BP; for example the site of Pisinmäki in Kerava (c. $20 \mathrm{~km} \mathrm{NE}$ of Lammaslampi) belongs to this period (Núñez 1978, a, b). So far Vantaa has not yielded any such early sites, and it is possible that the lack of dry land kept man away until the Ancylus regression had uncovered the Vantaa archipelago as a more favourable environment (see Fig. 1). There are, however, several sites datable to the Litorina period, among them the recently described sites of Kilteri and Jönsas, only about $3 \mathrm{~km}$ to the east of Lammaslampi (Núñez 1978 c). It is unlikely that human settlement interfered much with nature before the introduction of agriculture, and even then man's impact upon the environment must have been rather localized until more advanced intensive methods were adopted during historical times.

\section{Methods}

Cores for stratigraphical research were collected in February 1977 by boring at the 
LAMMASLAMPI, VANTAA, 60 $16^{\circ} \mathrm{N}, 2^{\circ} 48^{\prime} \mathrm{E}, 31.8 \mathrm{~m}$ a.s.I.

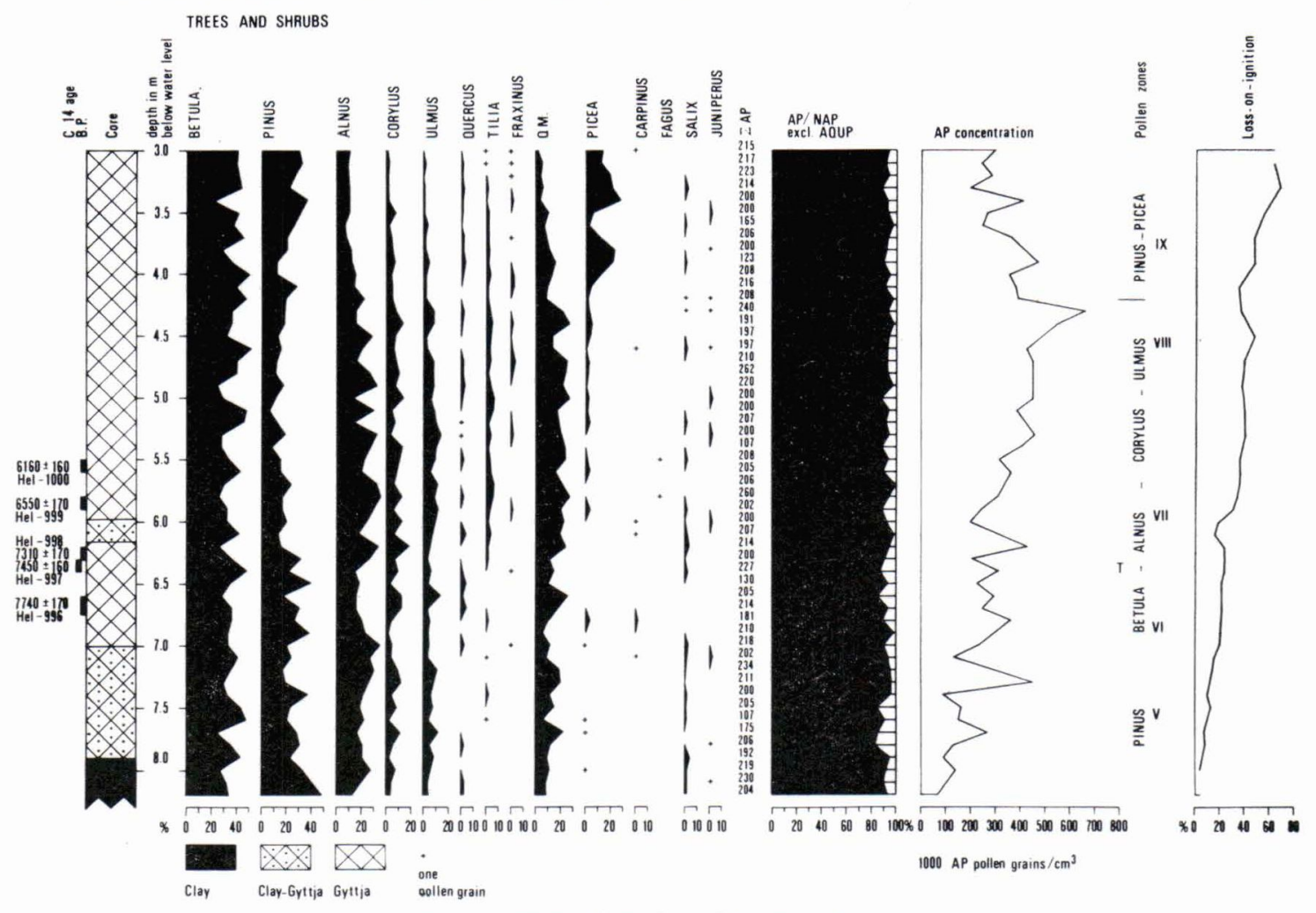

Fig. 2. Lammaslampi: pollen stratigraphy.

centre of the pond, where the depth was about $3 \mathrm{~m}$. The upper part of the sediment column was retrieved with a Livingstone corer and the lower one with a brass piston sampler. The thus obtained profile extends from the topmost layer to a grey clay layer. The thickness of the clay was not measured.

Pollen preparations were made from samples taken at $10-\mathrm{cm}$ intervals from the profile. About 200 AP were counted for most levels but at some points the count only reached to slightly over 100 AP. Stockmarr's Lycopodium tablets were employed to calculate absolute pollen concentrations.

Diatoms were examined at intervals of $5-10 \mathrm{~cm}$ from the lower portion of the profile, from the base to the lower layers of the muds deposited after isolation.

\section{Composition of the sediment column}

The first four metres of the sediment column from Lake Lammaslampi consist of gyttja (humus content more than $20 \%$ ) being interrupted at $6 \mathrm{~m}$ by a c. $20 \mathrm{~cm}$ thick layer of clay gyttja indicating the Litorina transgression. Below the transgressive layer the humus content gradually diminishes to $20 \%$ (the maximum content of clay gyttja) at $7 \mathrm{~m}$ below the water surface, to $6 \%$ (resp. gyttja clay) at $7.8 \mathrm{~m}$ and to $2 \%$ (resp. clay) at $8.2 \mathrm{~m}$, i.e. at the base of the column studied. A small amount of calcium carbonate below $7 \mathrm{~m}$ affects the loss-on-ignition values (see Fig. 2) which should be lowered by about one percent unit at $7 \mathrm{~m}$ and by 2 percent units at the base. The humus content of the basal 


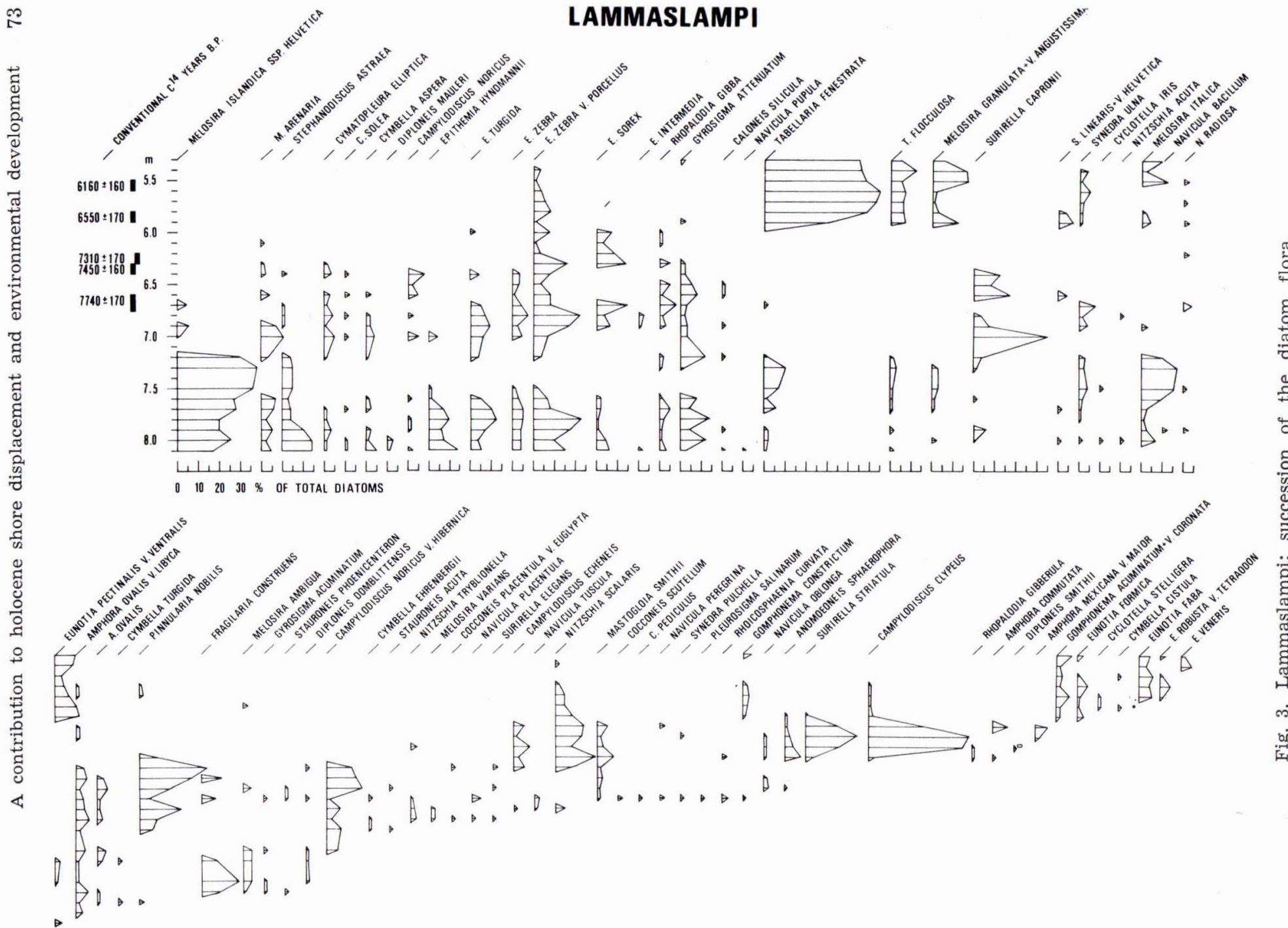




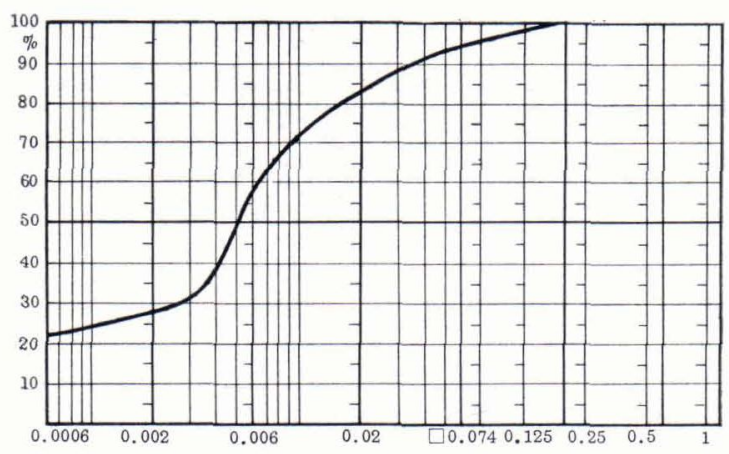

Fig. 4. Cumulative curve of the clayey silt from the base of the core $(8.2 \mathrm{~m})$, drawn according to areometrical results.

clay does not differ from that characteristic to the Ancylus sediments of southern Finland in general (see Gardemeister 1975, p. 46), whereas in the overlying sediments it is remarkably higher than the average values, which indicates shallow water conditions at the time of deposition, towards the end of the Ancylus stage.

The cumulative curve of Fig. 4 represents the size composition of the basal clay from $8.2 \mathrm{~m}$ below the water surface. The proportion of clay-size (less than $0.002 \mathrm{~mm}$ ) fractions is $28 \%$, which is less than the clay content generally characteristic of the Ancylus sediments in southern Finland (see Gardemeister 1975, p. 45).

The loss-on-ignition at $550^{\circ} \mathrm{C}$ for $1 \mathrm{~h}$ was recorded from samples taken at every $10 \mathrm{~cm}$ along the profile. The mineral composition of the clayey base was determined by $x$-ray diffraction. Five radiocarbon determinations served to date the local shoreline displacement.

To find out the mineralogical composition $x$-ray diffraction analyses were made from the core at points $7.2,7.7$ and $8.2 \mathrm{~m}$ below the water surface.

Quartz was the principal mineral component throughout the sample series. It was followed by plagioclase, potassium feldspar and mica. Judging by the diffuse reflection (at $10.4-10.0 \AA$ ) of the mica (biotite) in the unheated samples and by the sharp and more intense one at $10.0 \AA$ in the samples heated to $550^{\circ} \mathrm{C}$, small amounts of vermiculite are probably mixed in the crystal layers of the mica. Very weak reflections of chlorite, amphibole and calcite were also recorded. The amount of calcite decreased towards the surface. No reflections of this mineral were observed in the diffraction diagram from the $7.2 \mathrm{~m}$ sample below the water surface, although the $\mathrm{HCl}$ test still indicated its presence. The mineralogical composition does not differ in principle from that found earlier in the Quaternary clays of southern Finland (see Soveri 1956, Gardemeister 1975). The mineralogy of the sediments indicates a source of unweathered, principally acid rocks, typical of the Precambrian bedrock in southern Finland. According to Härme $(1959,1969)$ the local bedrock consists mainly of migmatites (quartz-feldspar schists with granitic veins). The southeastern rim of the postorogene massif of Bodom granite lies only $3 \mathrm{~km} \mathrm{NW}$ (i.e. against the direction of the movement of the Pleistocene ice sheets) from Lake Lammaslampi. Carbonate-bearing rocks occur in the area as small lenses, mainly in connection with the quartz-feldspar schists and diopside gneisses.

\section{Pollen stratigraphy}

The pollen analysis did not provide enough grounds to date the sediments, the lower levels being particularly difficult to interpret.

The pollen flora at the base of the profile is typical of the Holocene climatic optimum: at the depth of $8.2 \mathrm{~m}$ the proportion of Pinus is over $40 \%$, but also Betula and Alnus are respectively over $30 \%$ and $10 \%$ with $3 \%$ Ulmus, $4 \%$ Corylus and $2 \%$ Quercus. By $8 \mathrm{~m}$ Pinus has decreased to slightly over $30 \%$ and Betula to a little less than $30 \%$, 
but Alnus has on the other hand increased to over $25 \%$ with Ulmus and Corylus at $6 \%$ and $7 \%$ respectively. No other important changes occur above the 8-m level for a long interval.

The described pollen flora does not quite fit the general framework reflected by the nature of the sediments, the diatom analysis and the radiocarbon dates. The base of the profile is a clay that according to its diatoms was deposited into the Ancylus Lake. The transition from the fresh-water Ancylus Lake to the slightly saline Mastogloia phase took place around 8000 radiocarbon years ago in SW Finland (see Eronen 1974, 111-114). A sample from a clayey mud layer $(6.75-6.60$ m) dated the Mastogloia phase at Lammaslampi to $7740 \pm 170 \mathrm{BP}$. A second date of $7450 \pm 160 \mathrm{BP}$ was obtained from a sample $20 \mathrm{~cm}$ higher in the profile. If the rate of sediment accummulation had remained relatively unchanged, sedimentation around 8000 BP would have occurred at a depth of about $7 \mathrm{~m}$, i.e. some $20 \mathrm{~cm}$ below the mentioned level. Since major changes in the rate of sedimentation are not likely, the base of the sample column most probably dates to $8000 \mathrm{BP}$.

However, the pollen stratigraphy does not quite agree with the above interpretation. Around $8000 \mathrm{BP}$ a clear rise of Alnus should be observable in the pollen diagrams of southern Finland (cf. Donner 1971; Eronen 1976). The base of the sample column should be older than this event, falling within the Pinus Pollen Assemblage Zone for southwestern Finland (cf. Donner 1971) or, cronostratigraphically, within the Boreal chronozone (cf. Mangerud et al. 1975). In view of the contradictory nature of the pollen flora it must be concluded that the base of the sediment series is rich in re-deposited pollen.

Therefore pollen analysis is of little help in dating the basal portion of the profile. The same type of problem has been observed before, for example in the Bastuberg bog near Porvoo (see Eronen 1974: 177 and supplement) where Alnus pollen also occurs abundantly all the way down the base of the profile. When the radiocarbon determinations pointed to a date over $8000 \mathrm{BP}$, there too the interpretation was re-deposited pollen. Already as early as 1949 , Sauramo advanced the opinion that pollen analysis of southernFinnish clayey Late-glacial deposits did not give a correct picture of the vegetation development on account of this re-deposition phenomenon. Apparently some Postglacial clayey sediments are rich in re-deposited pollen, too. Donner and Gardemeister (1971) have shown that the clay deposits of Somero, in SW Finland, were very rich in Eem interglacial pollen. Similarly it is probable that some of the Late-Weichselian and early Flandrian clays are also rich in interstadial (Peräpohjola?) pollen.

The first clear pollen stratigraphical horizon in the lower part of the profile is the beginning of the continuous Tilia curve at a depth of $6.4-6.3 \mathrm{~m}$. This horizon has yielded a radiocarbon age of $7450 \pm 160 \mathrm{BP}$. It does not differ significantly from the date obtained from a comparable horizon at Gallträsket, a small lake in Kauniainen, about $6 \mathrm{~km}$ to the SW of Lammaslampi. The date obtained at Gallträsket was $7410 \pm 250$ (Hel-351, Eronen 1974). On the basis of these two dates, the spread of Tilia in the Helsinki district took place $7500-7400$ radiocarbon years BP.

Total pollen concentration were preliminarily calculated with the help of Stockmarr's Lycopodium tablets. The basal portion of the profile gave concentrations around 100000 grains per $\mathrm{cm}^{3}$. Moving upwards along the profile the values steadily increase, though showing broad fluctuations, until the level of the Picea rise: from $100000 / \mathrm{cm}^{3}$ at the base to over $400000 / \mathrm{cm}^{3}$ at the lower portion of the upper core and over $650000 / \mathrm{cm}^{3}$ at 4.3 
$\mathrm{m}$, close to the level of the Picea rise. Above this point, in the Pinus-Picea R. (SW Finland) P.A.Z. the values decrease so that the topmost sediment layers have pollen concentrations of $200000-300000$ grains per $\mathrm{cm}^{3}$.

The considerable fluctuations in absolute pollen concentrations are apparently relatable to the sedimentation conditions of the basin. Anyhow the results show common traits with those reported by Donner (1972) in his investigations at Lake Vakojärvi.

\section{Macrosubfossils}

The Lammaslampi samples were not examined for macrofossils, but nevertheless R. Uusinoka accidentally found a couple. These were discovered while breaking up the sediment for granulometrical analysis. One of them was a Myriophyllum spicatum leaf from a depth of $7.6 \mathrm{~m}$ and the other a fragment of an oak leaf. Both finds are described in more detail elsewhere (Aalto and Uusinoka 1978).

The oak leaf is particularly interesting. It was found within a muddy clay matrix at a depth of $8.1 \mathrm{~m}$. As mentioned earlier this portion of the profile must have been deposited over 8000 years ago. The diatoms at this level are typical of the Ancylus Lake stage, but the pollen flora does not quite agree with the rest of the stratigraphical evidence.

The percentage of Quercus at the level where the subfossil leaf was found was only $2 \%$. The question now arises: is it possible that oak already grew in the district over 8000 years ago? Generally Quercus does not occur very abundantly in pollen diagrams from southern Finland, and even this weak representation normally falls within the climatic optimum, i.e. R.P.A.Z Betula-Alnus -Corylus-Ulmus (8 000-2 $500 \mathrm{BP}$ ) for SW Finland according to Donner (1971). In other words, oak was not very common in southern Finland over 8000 years ago. An alternative possible explanation would be that the oak leaf is not in primary position. The pollen flora most probably contains redeposited material. But the preservation of a leaf throughout a glaciation episode is certainly a rare event, and the re-deposition of such leaf with the clay is highly improbable although not entirely impossible.

\section{Diatom stratigraphy}

Diatom analysis was applied to identification of the various stages of the Baltic as well as the question of the isolation of Lammaslampi. Fig. 3 presents the general stratigraphy of the diatoms and their associations.

The lower part of the profile at depths between 8.1 and $7.1 \mathrm{~m}$ is characterized by the dominance of clear water forms, showing that these sediments were deposited during the Ancylus Lake stage. The most common species were Melosira islandica ssp. helvetica, M. arenaria and Stephanodiscus astraea. Other species of clear water association were amongst others Cymatopleura elliptica, C. solea, Gyrosigma attenuatum, Campylodiscus noricus, C. noricus $v$. hibernica and Diploneis mauleri. Epithemiae were also well represented. Their importance decreases from 7.5 m upwards while plankton form Melosira islandica ssp. helvetica rises to a maximum $(38 \%)$ at $7.3 \mathrm{~m}$; Melosira italica also occurs abundantly at this level. The subsequent development between 7.2 and $6.9 \mathrm{~m}$, with the maxima of Melosira arenaria $(20 \%)$ and Surirella capronii $(35 \%)$ at $7.0 \mathrm{~m}$, already indicates a distinct littoral zone.

At $6.9-6.7 \mathrm{~m}$ brackish water diatoms make their appearance. First occur bottom forms such as Nitzschia tryblionella and N. scalaris, and later at $6.7 \mathrm{~m}$ epiphytic forms, for example, Mastogloia smithii, Synedra pulc- 
helia, Cocconeis scutellum, C. pediculus and Rhoicosphaenia curvata. In addition to these the occurrence of brackish water bottom forms as Navicula peregrina and Pleurosigma salinarum is worth mentioning. This diatom community suggests a shallow bay environment (see Florin 1946, Alhonen 1971: 11-12) and on chronological bases it can be taken to represent the Mastogloia phase in the diatom stratigraphy of Lammaslampi.

The brackish water forms are replaced a little higher in the profile $(6.6-6.4 \mathrm{~m})$ by fresh water benthonic forms (Surirella capronii, Pinnularia nobilis, Campylodiscus noricus and $C$. noricus $v$. hibernica), but from the depth of 6.3 upwards the brackish water forms become again important in a rapid succession. The flora is at this point characteristic of a Clypeus-lagoon, comprising the following species: Campylodiscus clypeus, Surirella striatula, Anomoeoneis sphaerophora, Nitszchia scalaris, Diploneis smithii and Amphora mexicana v. maior. Epithemiae also grew in this shallow lagoon of the Litorina Sea, especially E. sorex (see also Florin 1946; Alhonen 1971, 1972).

The isolation of Lammaslampi from a lagoon of the Litorina Sea can be observed at the $5.9 \mathrm{~m}$ level, where the Clypeus-flora practically disappears. Nitzschia scalaris continued to grow in the pond for some time, whereas Campylodiscus clypeus no longer occurs above $5.6 \mathrm{~m}$. The formation of an isolated basin is most clearly reflected in the diagram by Tabellaria fenestrata, $T$. flocculosa, Melosira granulata $v$. angustissima and $M$. italica.

\section{Stages of the Baltic and shoreline displacement}

At the time of the Ancylus transgression maximum around 9000 years ago, the vicinities of Lammaslampi were still covered by dozens of metres of water. The regression of the Ancylus Lake took place between 8900 and 8500 BP (Eronen 1974). During this regression period the highest points of the study area emerged as an archipelago. The lowering of the water level can be seen in the Lammaslampi sediments as an increase in their organic matter content. In the diatom stratigraphy the event is reflected by an increase in littoral species.

No exact information concerning water level fluctuations during the period comprising the end of the Ancylus Lake stage, the Mastogloia phase and the beginning of the Litorina Sea stage can be obtained from the Lammaslampi profile. It is apparent, as mentioned above, that Lammaslampi was a fairly shallow basin throughout this period. Possibly no major water level changes took place between c. $8500 \mathrm{BP}$ and c. $7500 \mathrm{BP}$. The basin was anyhow connected to the Baltic during this period: the diatoms indicate that Lammaslampi did not become an independent basin before the Litorina transgression.

The Mastogloia phase (cf. Eronen 1974, p. 146), preceded the Litorina Sea. This is shown by the appearance of a few brackish water species within an otherwise typical »Ancylusflora». It has been stated earlier that it had not been possible to identify the Mastogloia phase in previous investigations of cores taken from the coastal areas of the Gulf of Finland (see Eronen 1974). However, this phase is detectable at Lammaslampi as a slightly saline phase before the clearly saline Litorina Sea. The early Mastogloia phase was dated to $7740 \pm 170 \mathrm{BP}$, but the actual date for the beginning of the phase is probably somewhat older because the dated material was taken from above the transition level. The same transition level has been dated in SW Finland to $8070 \pm 250 \mathrm{BP}$ (Eronen 1974), this agreeing with the idea that the beginning of the phase is somewhat metachronic.

Similarly the beginning of the Litorina 
stage is also metachronic: the date previously obtained for the beginning of this phase in coastal southern Finland is 7400-7300 BP and around $7000 \mathrm{BP}$ for the Ostrobothnian coast (Eronen 1974). The dates from Lammaslampi are thus in agreement with the previous dates. The increase in salt water diatoms - the so-called Clypeus flora - at Lammaslampi takes place at $6.2-6.3 \mathrm{~m}$. Two radiocarbon determinations have been from the interval $6.4-6.2 \mathrm{~m}$ in the profile: $7450 \pm$ $160 \mathrm{BP}(6.4-6.3 \mathrm{~m})$ and $7310 \pm 170 \mathrm{BP}(6.3-$ $6.2 \mathrm{~m})$. On this basis the date for the beginning of the Litorina Sea is around 7300 BP.

The beginning of the Litorina Sea is associated with a transgressive event that affected southeastern Finland, reaching to the Helsinki district. The amplitude of this transgression at Gallträsket has been calculated to around $2 \mathrm{~m}$ (Eronen 1974). The transgression at Lammaslampi can be estimated to about the same magnitude even though its upper and lower limits are not readily available. The transgression is clearly indicated by the change to more mineral-rich sediments at the beginning of the Litorina stage (see the loss-on-ignition curve in Fig. 2). By interpolating the "bend" of the losson-ignition curve it is possible to estimate the date of the local Litorina transgression maximum to about $7000 \mathrm{BP}$. The altitude of the highest Litorina shore at Lammaslampi was probably $34-35 \mathrm{~m}$, or $2-3 \mathrm{~m}$ above the threshold (cf. Eronen 1974; Núñez 1978 b).

At the Lammaslampi isobase the Litorina transgression had already ended before 6500 $\mathrm{BP}$, when the eustatic rise of the ocean slowed down allowing the local isostatic uplift to become dominant. The basin became isolated from the Baltic in $6550 \pm 170 \mathrm{BP}$ according to the radiocarbon date. Most of the brackish water diatoms at this level (5.9$5.8 \mathrm{~m}$ ) give way to small lake species, but even after isolation a few halophilous species continued to grow in the lake until their disappearance at $5.6-5.5 \mathrm{~m}$ level dated to $6160 \pm 160 \mathrm{BP}$. There is an earlier radiocarbon date for the isolation of Lake Gallträsket, which is situated closeby at $31 \mathrm{~m}$ a.s.l. According to this date Gallträsket was isolated from the Litorina Sea $6180 \pm 230$ BP (Eronen 1974). These dates suggest that the shore displacement in the area was rather slow between 6500 and $6000 \mathrm{BP}$.

The isolation level is also observed in the loss-on-ignition curve as a clear increase in organic matter.

Acknowledgements - The authors wish to thank the students of the 1977 Quaternary Paleontology cum laude course, who helped in the field and laboratory work.

\section{References}

Aalto, M. and Uusinoka, R. (1978) 8000-year-old Quercus and Myriophyllum leaves from bottom clays of a lake in southern Finland. Memor. Soc. Fauna Flora Fennica 54: 7-11.

Alhonen, P. (1971) The stages of the Baltic Sea as indicated by the diatom stratigraphy. Acta Bot. Fennica 92.18 p.

- (1972) Gallträsket: The geological development and palaeolimnology of a small polluted lake in southern Finland. Comment. Biol. 57. 34 p.

Donner, J. (1971) Towards a stratigraphical divi- sion of the Finnish Quaternary. Comment. Phys.-Math. 41: 281-305.

- (1972) Pollen frequencies in the Flandrian sediments of Lake Vakojärvi, South Finland. Comment. Biol. 53. 19.

- and Gardemeister, R. (1971) Redeposited Eemian marine clay in Somero, south-western Finland. Bull. Geol. Soc. Finland 43: 73-88.

Eronen, M. (1974) The history of the Litorina Sea and associated Holocene events (Supplement: 
Pollen and diatom diagrams). Comment. Phys.Math. 44(4): 79-195.

- (1976) A radiocarbon dated Ancylus transgression site in south-eastern Finland. Boreas 5: $65-76$.

Florin, M.-B. (1946) Clypeusfloran i postglaciala fornsjölagerföljder i östra Mellansverige. Geol. Fören. Förh. 68: 429-458.

Gardemeister, R. (1975) On engineering-geological properties of fine-grained sediments in Finland. Technical Research Centre of Finland, Building Technology and Community Development. Publ. 9. 91 p.

Hyyppä, E. (1937) Post-glacial changes of shoreline in South Finland. Bull. Comm. Géol. Finlande $120,225 \mathrm{p}$.

- (1950) Helsingin ympäristö. Maaperäkartan selitys. Geologinen tutkimuslaitos, $11-53$.

Härme, M. (1959) Kallioperä. Pp. 9-11 in Maaperäkartan selitys, 2043 Kerava, ed. by $\mathrm{K}$. Virkkala, Suomen Geologinen kartta, 1 : 100000. Geologinen tutkimuslaitos.

- (1969) [Map of Pre-Quaternary rocks], 2043 Kerava. Geological map of Finland, $1: 100000$. Geologinen tutkimuslaitos.
Mangerud, J., Andersen, S. T., Berglund, B. E. and Donner, J. J. (1974) Quaternary stratigraphy of Norden, a proposal for terminology and classification. Boreas 3: 109-128.

Núñez, M. (1978 a) On the date of the early Mesolithic settlement of Finland. Suomen Museo 1977 (in press).

- $(1978 \mathrm{~b})$ A model to date Stone Age sites within the area of abnormal uplift in southern Finland. Oikos 2 (in press).

- $(1978 \mathrm{c})$ The Vantaa phospate survey: a practical illustration of the method. Ann. Acad. Scient. Fennicae A III (in press).

Sauramo, M. (1949) Das dritte Scharnier der fennoskandischen Landhebung. Soc. Sci. Fennica - Årsbok - Vuosikirja 27 B, 4: 1-26.

- (1958) Die Geschichte der Ostsee. Ann. Acad. Scient. Fennicae A III 51. 522 p.

Soveri, U. (1956) The mineralogical composition of argillaceous sediments of Finland. Ann. Acad. Sci. Fennicae A III 48.

Manuscript received, May 24, 1978. 